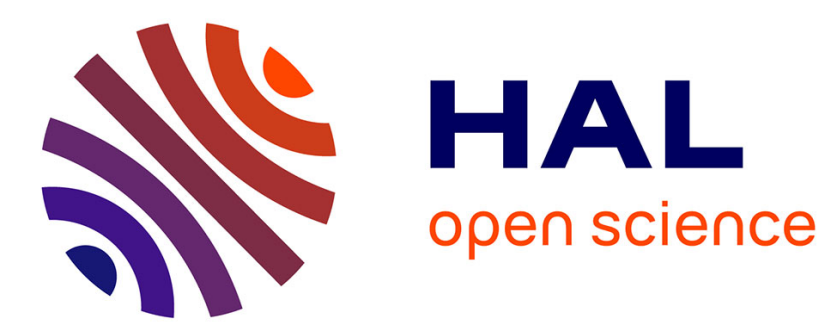

\title{
Logical Necessity in Class Inclusion Development and the Ability to Process Transformations
}

Patrick Perret

\section{To cite this version:}

Patrick Perret. Logical Necessity in Class Inclusion Development and the Ability to Process Transformations. Journal of Cognitive Education and Psychology, 2004, 4, pp.220 - 231. hal-01779351

\section{HAL Id: hal-01779351 \\ https://hal.science/hal-01779351}

Submitted on 26 Apr 2018

HAL is a multi-disciplinary open access archive for the deposit and dissemination of scientific research documents, whether they are published or not. The documents may come from teaching and research institutions in France or abroad, or from public or private research centers.
L'archive ouverte pluridisciplinaire HAL, est destinée au dépôt et à la diffusion de documents scientifiques de niveau recherche, publiés ou non, émanant des établissements d'enseignement et de recherche français ou étrangers, des laboratoires publics ou privés. 


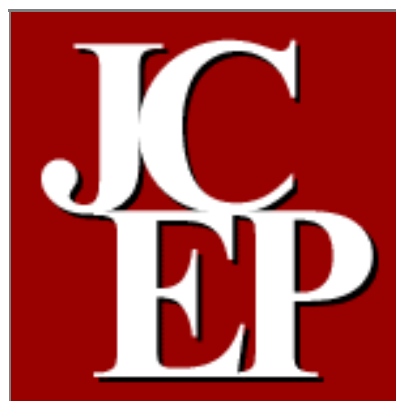

Journal of Cognitive $\mathbf{E}_{\text {ducation and }} \mathbf{P}_{\text {sychology }}$

online

Volume 4, Number 2, September, 2004

A peer-reviewed publication of

The International Association for Cognitive Education and Psychology

Editor H. Carl Haywood, Vanderbilt University

Book Review Editor Martin B. Miller

Editorial Board

Adrian Ashman, University of Queensland

Laura Berk, Illinois State University

John Borkowski, University of Notre Dame

Fredi Büchel, University of Geneva

Roberta Garbo, University of Milan

Ted Hasselbring, University of Kentucky

Marco Hessels, University of Geneva

Earl Hunt, University of Washington

Yuriy V. Karpov, Touro College

Santiago Molina, University of Zaragoza

Jean-Louis Paour, University of Provence

Scott Paris, University of Michigan

Juan Pascual-Leone, York University

Hélène Poissant, University of Quebec at Montreal

Ursula Scharnhorst, University of Geneva

David Tzuriel, Bar Ilan University

Theodore D. Wachs, Purdue University

Karl H. Wiedl, University of Osnabrück

\section{Technical Editor Sara Swan Miller}

Perret, Patrick (2004). Logical Necessity in Class Inclusion Development and the Ability to Process Transformations. Journal of Cognitive Education and Psychology [online], 4, 2, 220-231. www.iacep.coged.org 


\title{
Patrick Perret
}

\section{Université de Provence}

\section{Logical Necessity in Class Inclusion Development and the Ability to Process Transformations ${ }^{1}$}

\begin{abstract}
The use of Markman's modification task in the study of class inclusion development revealed a developmental gap between the ability to compare the extensions of classes and subclasses and the understanding that the superiority of the class extension is a logical necessity. Barrouillet and Poirier (1997) have proposed that the main difficulty in Markman's task lies in its demand for the processing of transformations. Indeed, necessity arises from the impossibility of transforming facts. The present study explores this hypothesis by comparing children's performances on a task of logical necessity and a task that requires them to process transformations of class extension. The results, consistent with Barrouillet and Poirier's view, are discussed with reference to Piaget's morphism theory and Halford's relational complexity theory.
\end{abstract}

Key words: cognitive development, class inclusion, logical necessity, relational complexity, transformation

Class inclusion development refers to children's gradual understanding that (a) most categories are hierarchically arranged with inclusion relationships, and (b) this hierarchical organization allows both extensional and intensional inferences (i.e. relative to the number of members that form the categories and relative to the features of those members). Research in this field has been deeply influenced by Piaget's extensional approach and his famous class inclusion task. This task requires children to compare the extension of a class with the extension of one of its subclasses (e.g., given 10 roses and 5 daisies, are there more flowers or more roses?). Thus, Piaget's criterion for a mature

\footnotetext{
${ }^{1}$ The author would like to thank Christine Bailleux, Agnès Blaye, and Jean-Louis Paour for their many contributions to this research. This work is based on the author's doctoral dissertation. Perret, P. (2001). Etude développementale de la variabilité des performances dans des tâches de raisonnement inclusive: Rôle des niveaux de connaissance et de l'inhibition. University of Provence. Dissertation advisors: Agnès Blaye and Jean-Louis Paour.
} 
understanding of the inclusion relationship lies in the understanding of the extensional consequences of this relationship.

An impressive number of post-Piagetian studies have been dedicated to exploring the effects of task changes on the age of acquisition of this competence. This research flow has been oriented toward demonstrating that performance on the task may vary as a function of perceptual or linguistic factors such as intermingling the subsets (Gold, 1987) or adding verbal clues to the wording of the class inclusion question (Shipley, 1979). Many of these studies remained quite uninformative from a developmental standpoint inasmuch as they did not address important theoretical issues such as the developmental significance of cross-task performance variability (Sophian, 1997) and the existence of qualitatively different levels of knowledge in class inclusion development (Perret, Paour, \& Blaye, 2003).

These issues arise from one of the crucial results in the field of class inclusion development: The discovery by Voelin (1976) and Markman (1978) that children who succeed on Piaget's class inclusion task may nonetheless consider that there could be more roses than flowers, for example by adding roses. The "modification task" used by Markman consists of posing an additional question to the children who correctly answer that there are more elements in the class (B) than in the subclass (A): "Could we do something to make it so we have more As than Bs?" A similar task, the "Screen task," consists of placing a screen between the material and the child and saying "I'm going to take some Bs away..." before asking again the class inclusion question. The surprising failure on these tasks up to a mean age of 10 years led Bideaud (Bideaud \& Lautrey, 1983; Bideaud, 1988) to consider that understanding of class inclusion develops in two steps: considering facts (there are more Bs than As) and recognizing the necessity of that conclusion (it could not be otherwise). Smith (1982) emphasized this distinction: "It is, therefore, one thing to make a correct claim about the observed properties of an object; it is quite another to realize that a certain claim is a necessarily true one" (p. 268). Since the stating of this distinction, the central issue in class inclusion development has become: Beyond recognizing the fact that there are more Bs than As, how do children grasp the logical necessity of this fact, and why do they grasp it so late during their cognitive development?

Several theoretical explanations have been proposed. One set of explanations is focused on performance factors such as conversational awareness (Siegal, 1999) or inhibitory demands (Houdé, 2000) that might explain failures on class inclusion tasks. Others try to specify the developmental mechanisms that might underlie the transition between different levels of knowledge concerning class inclusion relationships, for example constructive generalization (Cormier \& Dagenais, 1983), reflective abstraction (Campbell \& Bickhard, 1986), or processing of negation operations (Müller, Sokol \& Overton, 1999). The answer that will be considered in this study is based upon the following argument that Piaget emphasized in his "Essay on Necessity" (1986): A fact( $p$ ) will be considered as necessary if its negation (not- $p$ ) is considered as impossible. That is, necessity does not arise from facts but from the transformations that one can or cannot apply to these facts. In line with this argument, Barrouillet and Poirier (1997) proposed 
that the transition from the factual to the necessary in children's judgments may be linked to their ability to process transformations. Markman (1978) and Bideaud (1988) considered that the main difficulty in the Modification task or in the Screen task lies in the impossibility of empirical comparisons between the two sets (spatial or numerical comparisons of the extensions). Barrouillet and Poirier's view is that logical necessity tasks not only require children to reason on non-observable states but mostly require them to consider transformations of these states. This cognitive demand clearly appears when one considers the experimenter's wording in the Modification or Screen tasks: "I take away a few flowers...", "Could we do something...", "If I add roses..." Thus, children's understanding of logical necessity may rely on their ability to represent mentally those transformations within a class inclusion system in which any change in the extension of a subclass covaries with a change in the extension of the class, making A $>\mathrm{B}$ impossible and, as a consequence, $\mathrm{B}>\mathrm{A}$ necessary. The present study was designed to explore this hypothesis by comparing children's performance on the Modification task and a Transformation task.

\section{Method}

\section{Participants}

Participants were 54 French children from second to fifth grade, ranging in age from 7 years 6 months to 11 years 3 months (mean age $=9$ years 5 months). Each of the children who participated in the study had passed a class inclusion pretest, giving correct answers on at least two standard Piagetian class inclusion questions.

\section{Material and procedure}

Children were tested individually in a 15-minute session during which they completed three tasks: a class inclusion pre-test, the Modification task, and the Transformation task.

Pre-test

The pre-test consisted of three class inclusion items: "Are there more As or more Bs?" administered with three different visual presentations: "standard," "boxes," and "intermingling" (see Figure 1). Three different categories were used and counterbalanced with the three presentations (Fruits: apples and bananas; Musical instruments: violins and trumpets; Flowers: daisies and tulips). Children had to answer correctly on at least two of the three questions to be included in the study. 


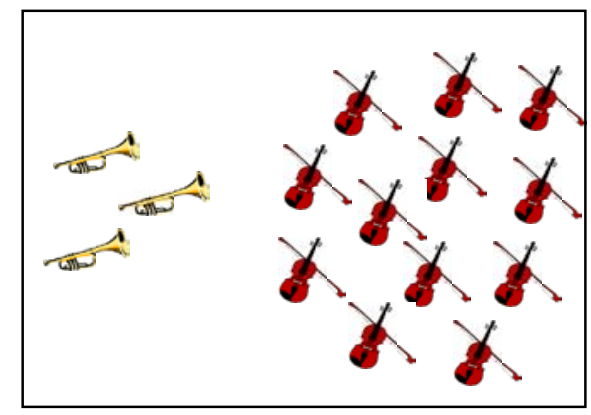

"Standard" condition

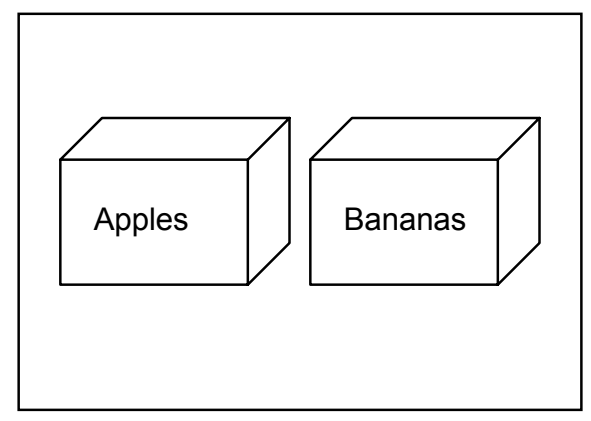

"Boxes" condition

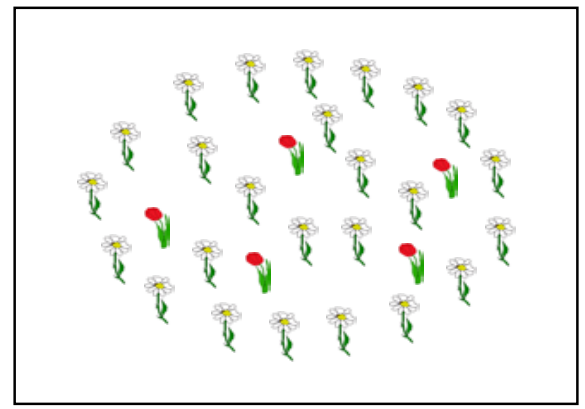

"Intermingling" condition

Figure 1. Three conditions of the class inclusion pre-test.

Modification Task

Children were shown again the first item on which they provided a correct answer during the pre-test. The experimenter reminded the child of his or her response to the class inclusion question and then asked: " I agree with you that there are more Bs than As. Now, could we do something to make it so that there will be more As than Bs?"

Transformation task

The Transformation task was designed to assess children's ability to consider the effects of transformations within the relational system of classes and subclasses, that is, any change in the extension of a subclass covaries with a change in the extension of the class. The child was shown a little container with 20 cards inside, each card representing the drawing of an animal: five of cows, five of dogs, five of lions, and five of sheep. The child was asked to name each of the subclasses represented in the container and to find a common word to refer to all of them (i.e., "animals"). The experimenter took four cards of cows from the container and put them on the table. He then said: "There are four cows on the table. I would like you to do something to make it so that there will be more animals than cows on the table". If the child spontaneously put more than one other card on the table, the experimenter introduced an additional constraint: "I agree with you that there are now more animals than cows on the table but I would like you to do so with as few cards as possible." The task was considered as correctly solved if, following this constraint, the child used only one non-cow card in addition to the four cows.

\section{Results}

Performances on the Modification task can discriminate between two groups of children with regard to their understanding of logical necessity in class inclusion relationships. Twenty-eight children provided a correct answer on the task, stating that nothing could be done to have more As than Bs (thereafter the "Logical Necessity Group"). Twenty-six children failed and judged that this fact could be modified, mainly by adding other As (thereafter the "No Logical Necessity Group"). In line with Barrouillet and Poirier's conception of logical necessity development, we predicted that these two groups should 
differ in their ability to process transformations within a class inclusion system, and then should differ in their performances on the Transformation task (see Table 1).

Table 1

Frequency of Success and Failure on the Transformation Task as a Function of Performance on the Modification Task

\begin{tabular}{lll}
\hline & \multicolumn{2}{c}{ Modification task } \\
\cline { 2 - 3 } Transformation task & No logical necessity & Logical necessity \\
\hline Success & 7 & 17 \\
Failure & 19 & 11 \\
\hline
\end{tabular}

The two groups differed significantly in their performances on the Transformation task $\left(\chi^{2}(1, \underline{N}=54)=6.25 ; \underline{p}<.05\right)$. Whereas a majority of children in the Logical Necessity group succeeded on the task, an inverse pattern of performance was observed in the No Logical Necessity group. If the overall result should favor the hypothesis, one should note however that 11 children in the Logical Necessity group failed on the Transformation task. See Discussion for further comment on this particular subgroup of children.

We further analyzed the results by comparing the performances of the two groups on the "Boxes" condition of the pre-test. Indeed, Bideaud's (1988) interpretation of children's failure on logical necessity tasks is that they cannot rely on empirical comparisons of the extensions. Given that the "boxes" condition of the pre-test requires children to reason on non-observable states, the two groups may also differ here. As the pre-test only involved succeeding on two items, children of the No Logical Necessity group should have succeeded on the two conditions for which empirical comparisons were possible but failed on the "boxes" condition. Results in Table 2 indicate that this was not the case ( ${ }^{2}$ $(1, \underline{\mathrm{N}}=54)=3,31 ; \underline{\mathrm{ns}})$. 
Table 2

Frequency of Success and Failure on the "Boxes" Condition of the Pretest as a Function of Performance on the Modification Task

\begin{tabular}{lll}
\hline & \multicolumn{2}{c}{ Modification task } \\
\cline { 2 - 3 } "Boxes" pretest & No logical necessity & Logical necessity \\
\hline Success & 20 & 27 \\
Failure & 6 & 1 \\
\hline
\end{tabular}

\section{Discussion}

The present results support Barrouillet and Poirier's view that the main feature of logical necessity tasks in class inclusion development is not to suppress empirical cues but rather to require children to process transformations of the extensions. As we had suggested, children's understanding of logical necessity seems to be bound up with their ability to consider co-variations of classes and subclasses' extensions. It was pointed out in the Results section that 11 of our participants exhibited a pattern of performance that conflicts with this hypothesis: They provided a logical answer on the Modification task while failing on the Transformation one. Further examination of their responses on the Transformation task revealed that six of them failed in a particular and qualitatively different way. Most of the children in the No Logical Necessity group (17 children out of 19) failed on the Transformation task in the sense that, despite the experimenter's instructions, they used more than one non-cow card to make it so that there would be more animals than cows. By contrast, most children in the Logical Necessity group (6 out of 11) failed in the sense that they did not use any animal at all, and merely refused to complete the task, stating that it was impossible. Our interpretation of such responses is that children did not really process the problem. Their answers may stem from an overgeneralization of the (correct) judgment that these children provided on the Modification task (where it was impossible to have more As than Bs), thus constituting a case of pseudo-necessity in Piaget's terms (Piaget, 1986). Beyond this particular subgroup of children, the overall results of the study are consistent with Piaget's later works based on the mathematical theory of morphisms: The transition between the ability to consider static states and the ability to process transformations may constitute an important facet of stages transition in many conceptual areas (Davidson, 1988). This study also appears to be in line with Halford's view of cognitive development as an 
experience-based acquisition of relational knowledge systems (Halford, Wilson, \& Phillips, 1997); when confronted with class inclusion problems, children have to consider the existence of a relational system between the extensions of classes and subclasses, with its variations, its possibilities, and necessities. With regard to this perspective, the relational complexity metric (Halford, Wilson \& Phillips, 1998) may help to explain the developmental gap between children's performances on Piaget's class inclusion task and their performances on the Modification or Transformation tasks. Given that a class inclusion hierarchy has three components (a class, a subclass, and a complementary subclass), class inclusion problems have been considered as implying the processing of ternary relations (Halford, Andrews \& Jensen, 2002). As soon as a transformation is applied to the extension of a subclass, the problem now involves four arguments, as shown in Figure 2 (the subclass extension before the transformation, the class extension before the transformation, the subclass extension after the transformation and the class extension after the transformation).

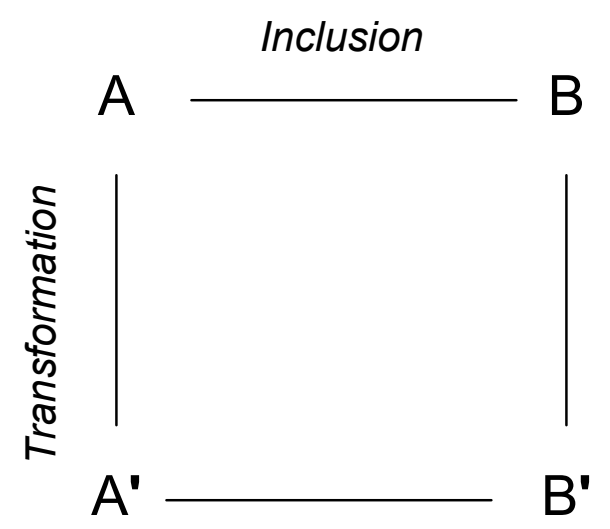

Figure 2. Number of variables involved in class inclusion problems with transformations.

As such, these extensional problems rely on quaternary relations rather than ternary relations in Halford's metric. Processing capacity constraints could then account for the late appearance of the understanding of logical necessity during class inclusion development, and will require further investigation.

\section{Implications for cognitive education}

Following Smith (1993), it can be argued that an important part of school learning is dedicated to necessary knowledge. This is obviously the case in mathematics and physics and, more generally, in the acquisition of scientific reasoning principles. Within the vast domain of necessary knowledge, necessities arising from inclusion relationships are involved in category formation and category use (intensional or extensional inferences) as well as in propositional reasoning (Müller, Sokol, \& Overton, 1999; Piaget, 2000). Our own work with adolescents who have learning disabilities has shown that they have difficulty grasping the logical necessity inherent in class inclusion relationships (Perret, 2001). 
The postulated role of processing capacity limits in the developmental sequence considered here should not be interpreted as precluding any role for experience, therefore for cognitive education. Halford made this point clear on several occasions:"the acquisition of any specific concept will depend, not only on development of the relevant capacity, but on experience...cognitive development is experience driven with processing capacity serving only an enabling role" (1999, p.204). The acquisition of relational knowledge relies on a process of abstraction that brings the child to detect regularities in the environment as well as in his/her own knowledge (Halford, Wilson \& Phillips, 1997). Within this broad constructivist framework, the present study highlights two phenomena:

(1) The first is the existence of qualitatively different knowledge levels within the same conceptual area (Campbell \& Bickhard, 1986). With regard to the particular domain of class inclusion, it should be considered that beyond the child's success on Piaget's task, a further step needs to be accomplished towards the understanding of logical necessity.

(2) Carrying out this further step requires providing the child occasions to process transformations: Appreciating the logical necessity of a fact derives from experiencing the impossibility of transforming it. As an example, several children in our sample seemed to discover, during the processing of the transformation task, that adding only one non-cow was sufficient to have more animals than cows. This means that, despite their available processing capacities, and despite their extensive scholarship experience with the semantic categories involved in the task, they simply never had the occasion to experience the transformational constraints inherent in the class inclusion system. Perhaps one task of cognitive education might be to provide those essential experiences.

\section{References}

Barrouillet, P., \& Poirier, L. (1997). Comparing and transforming: An application of Piaget's morphisms theory to the development of class inclusion and arithmetic problem solving. Human Development, 40, 216-234.

Bideaud, J. (1988). Logique et bricolage chez l'enfant_[Logical development during childhood]. Lille (France): Presses Universitaires de Lille.

Bideaud, J., \& Lautrey, J. (1983). De la résolution empirique à la résolution logique du problème d'inclusion : évolution des réponses en fonction de l'âge et des situations expérimentales [From empirical solution to logical solution of the inclusion problem: Evolution of responses as a function of age and experimental conditions]. Cahiers de Psychologie Cognitive,3, 295-326.

Campbell, R. L., \& Bickhard, M. H. (1986). Knowing levels and developmental stages. New York: Karger.

Cormier, P., \& Dagenais, Y. (1983). Class inclusion developmental levels and logical necessity. International Journal of Behavioral Development, 6, 1-14.

Davidson, P. M. (1988). Piaget's category-theoretic interpretation of cognitive development: A neglected contribution. Human Development, 31, 225-244. 
Gold, R. (1987). Class inclusion performance: Effect of intermingling the subsets. British Journal of Developmental Psychology, 5, 343-346.

Halford, G.S. (1999). The development of intelligence includes capacity to process relations of greater complexity. In M. Anderson (Ed.), The development of intelligence, 193-213, Hove: Psychology Press.

Halford, G.S., Andrews, G., \& Jensen, I. (2002). Integration of category induction and hierarchical classification: One paradigm at two levels of complexity. Journal of Cognition and Development, 3, 143-177.

Halford, G.S., Wilson, W.H., \& Phillips, S. (1997). Abstraction: Nature, costs, and benefits. International Journal of Educational Research, 27, 21-35.

Halford, G. S., Wilson, W. H., \& Phillips, S. (1998). Processing capacity defined by relational complexity: Implications for comparative, developmental, and cognitive psychology. Behavioral and Brain Sciences, 21, 803-865.

Houdé, O. (2000). Inhibition and cognitive development: Object, number, categorization and reasoning. Cognitive Development, 15, 63-73.

Markman, E. M. (1978). Empirical versus logical solutions to part-whole comparison problems concerning classes and collections. Child Development, 49, 168-177.

Müller, U., Sokol, B., \& Overton, W. F. (1999). Developmental sequences in class reasoning and propositional reasoning. Journal of Experimental Child Psychology, 74, 69-106.

Perret, P. (2001). Etude développementale de la variabilité des performances dans des tâches de raisonnement inclusif: rôle des niveaux de connaissance et de l'inhibition [Developmental study of performance variability in inclusive reasoning tasks: Role of knowledge level and inhibition]. Lille: ANRT

Perret, P., Paour, J-L., \& Blaye, A. (2003). Respective contributions of inhibition and knowledge levels in class inclusion development: A negative priming study. Developmental Science, 6, 283-288.

Piaget, J. (1986). Essay on necessity. Human Development, 29, 301-314.

Piaget, J. (2000). Studies in reflecting abstraction. Hove: Psychology Press.

Shipley, E. (1979). The class-inclusion task: Question form and distributive comparisons. Journal of Psycholinguistic Research $28,301-331$.

Siegal, M. (1999). Language and thought: The fundamental significance of conversational awareness for cognitive development. Developmental Science, 2, 1-34.

Smith, L. (1982). Class inclusion and conclusions of Piaget's theory. British Journal of Psychology, 73, 267-276.

Smith, L. (1993). The development of necessary knowledge: Psychological and educational issues. Early Child Development and Care, 95, 3-22.

Sophian, C. (1997). Beyond competence: The significance of performance for conceptual development. Cognitive Development, 12, 281-303.

Voelin, C. (1976). Deux experiences à propos de l'extension dans l'épreuve de la quantification de l'inclusion [Two studies of extension in the test of quantification of inclusion]. Revue Suisse de Psychologie, 35, 269-284. 


\section{Address for correspondence:}

Patrick Perret

Université de Provence

Département de Psychologie Développementale et Différentielle

29 Avenue Robert Schuman

13621 Aix en Provence

France

\section{$\underline{\text { Patrick.Perret@univ-aix.fr }}$}

\section{Résumé}

Nécessité Logique et Traitement des Transformations dans le Développement de l'Inclusion

L'utilisation des épreuves modifiées d'inclusion (Voelin, 1976; Markman, 1978) a révélé l'existence d'une différence développementale importante entre (a) la capacité de l'enfant à juger qu'il y a plus d'éléments dans une classe que dans l'une de ses sousclasses et (b) sa compréhension de la nécessité logique de la supériorité de la classe. Pour Barrouillet et Poirier (1997), la principale difficulté des épreuves modifiées (épreuves dites «Modification» ou «Ecran») réside dans le fait qu'elles demandent aux enfants de considérer des transformations dans les extensions : la nécessité logique d'un fait découle de l'impossibilité de le transformer. L'étude présentée ici explore cette hypothèse en mettant en regard la performance des enfants à une épreuve de nécessité logique et à une épreuve impliquant de traiter une transformation des extensions dans un système d'inclusion. Les résultats, qui apparaissent cohérents avec la conception de Barrouillet et Poirier (1997) sont discutés à la lumière des derniers travaux de Piaget sur les morphismes, et des propositions d'Halford sur les liens entre développement cognitif et complexité relationnelle.

\section{Resumen}

\section{Necesidad Lógica en el Desarrollo de la Inclusión de Clases y Habilidad para Procesar Transformaciones}

El uso de la modificación de tareas de Markman en el estudio del desarrollo de la inclusión de clases reveló un vacío evolutivo entre la habilidad para comparar las extensiones de clases y subclases; asimismo que la comprensión de la superioridad de la extensión de clases es una necesidad lógica. Barrouillet y Poirier (1997) han 
propuesto que la principal dificultad en las tareas de Markman radica en sus demandas para el procesamiento de la información. En efecto, dicha dificultad proviene de la imposibilidad de transformar los hechos. El estudio que se presenta en el artículo explora esa hipótesis a través de la comparación de los resultados de los niños en tareas de necesidad lógica $\mathrm{y}$ en otras que le exigen procesar transformaciones de extensión de clases. Los resultados, consistentes con los puntos de vista de Barrouillet y Poirier, son analizados con referencia a la teoría isomorfa de Piaget y a la teoría relacional compleja de Halford.

\section{Zusammenfassung}

Lokale Notwendigkeit bei der Entwicklung der Klasseninklusion und der fähigkeit zur Verarbeitung von Transformationen

Die Verwendung von Markmans Modifikationsaufgabe bei der Untersuchung der Entwicklung der Klasseninklusion enthüllte eine Entwicklungslücke zwischen der Fähigkeit, die Erweiterung von Klassen und Subklassen zu vergleichen und dem Verständnis, dass die Überlegenheit der Klassenextension eine logische Notwendigkeit ist. Barrouillet und Poirier (1997) haben die Vermutung formuliert, dass die Hauptschwierigkeit in Markmans Aufgabe in ihrer Anforderung liegt, Transformationen zu verarbeiten. In der Tat entsteht Notwendigkeit aus der Unmöglichkeit des Transformierens von Fakten. Die vorliegende Studie untersucht diese Hypothese durch den Vergleich der Performanz von Kindern bei einer Aufgabe der logischen Notwendigkeit und einer Aufgabe, die die Verarbeitung von Transformationen von Klassenerweiterungen erfordert. Die Ergebnisse, die mit der Auffassung von Barrouillet und Poirier übereinstimmen, werden in Bezug auf Piagets Theorie des Morphismus und Halfords Theorie relationaler Komplexität diskutiert.

\section{Abstract Italiano \\ La NecessitàLlogica nello Sviluppo dell' Inclusione di Classe e nel Processamento delle Trasformazioni}

L'impiego del compito di modificazione di Markman nel quadro di uno studio sullo sviluppo dell'inclusione di classe ha messo in luce uno scarto evolutivo tra la capacità di confrontare l'estensione di classi e sottoclassi e la comprensione del fatto che la superiorità dell'estensione della classe sia una necessità logica. Barrouillet e Poirier (1997) hanno avanzato l'ipotesi che la difficoltà principale nel compito di Markman risieda nel fatto che esso comporti il 
processamento di trasformazioni. In effetti, la necessità scaturisce dalla impossibilità di trasformare i fatti. Lo studio esplora tale ipotesi confrontando le prestazioni dei bambini su un compito di necessità logica e un compito che richiede loro il processamento di trasformazioni per l'estensione di classe. I risultati, coerenti con le posizioni di Barrouillet e Poirier, vengono discussi facendo riferimento alla teoria Piagetiana del morfismo e a quella della complessità relazionale di Halford. 